JAKUB KUFEL

Instytut Politologii UMK

\title{
Wybory czerwca 1989 r. w okręgu toruńskim
}

\section{Wstęp}

brady Okrągłego Stołu w Polsce zakończyły się 5 kwietnia 1989 roku. Przedstawiciele władzy oraz opozycji zawarli porozumienie, w myśl którego w czerwcu 1989 roku miały się odbyć kontraktowe wybory do parlamentu. Według postanowień, 65\% miejsc w sejmie zagwarantowano kandydatom strony rządowej ${ }^{1}$, zaś o pozostałe $35 \%$ mandatów ubiegali się kandydaci bezpartyjni.

Ordynację wyborczą do parlamentu regulowała ustawa z 7 kwietnia 1989 r. o zmianie Konstytucji Polskiej Rzeczypospolitej Ludowej. W myśl jej przepisów w Sejmie miało zasiadać 460, w Senacie zaś 100 parlamentarzystów. Byli oni wybierani w głosowaniu równym, bezpośrednim i tajnym - na okres 4 lat. Wyborcy mieli możliwość oddawania głosów na kandydatów do Sejmu i Senatu w okręgach wyborczych. Kandydaci na posłów mogli także startować z tzw. krajowej listy wyborczej, z której to mandat uzyskiwała osoba, która otrzymała powyżej 50\% poprawnie oddanych głosów ${ }^{2}$.

ówczesnemu województwu toruńskiemu, które stanowiło jeden okręg wyborczy, przyznano 2 mandaty w wyborach do senatu. Równocześnie, Toruniowi tworzącemu jeden okręg $\mathrm{w}$ ramach elekcji do sejmu, zagwaranto-

Polskiej Zjednoczonej Partii Robotniczej, Zjednoczonego Stronnictwa Ludowego, Stronnictwa Demokratycznego oraz prokomunistycznych organizacji katolickich Stowarzyszenia PAX, Unii Chrześcijańsko - Społecznej, Polskiego Związku Katolicko - Społecznego.

2 Zob. Dokumenty Życia Społecznego, sygn. XXI - 3, Zmiany w Konstytucji PRL. Ordynacje wyborcze do Sejmu i Senatu, Warszawa 1989, s. 24 i nast. 
wano 4 mandaty poselskie. 0 ile wybory do Senatu były w pełni wolne, o tyle w przypadku Sejmu tylko o dwa mandaty mogli ubiegać się przedstawiciele opozycji ${ }^{3}$. Mechanizm wyborczy prezentował się następująco: do parlamentu w pierwszej turze wyborów dostawał się ten kandydat, na którego głos oddało powyżej 50\% uprawnionych do głosowania. Jeśli żadna z osób ubiegających się o mandat nie przekroczyła tego progu, w drugiej turze wystarczyła zwykła większość głosów .

Wybory do senatu nadzorowała Wojewódzka Komisja Wyborcza. W jej skład w Toruniu wchodziło 17 osób, z czego tylko 5 było członkami NSZZ „Solidarność" 5 . Z kolei elekcję do sejmu obsługiwała Okręgowa Komisja Wyborcza. Aby uzyskać pewność, że w trakcie wyborów nie dojdzie do nadużyć, każdy z kandydatów mógł zgłaszać mężów zaufania do komisji okręgowych. Mieli oni prawo przebywania w lokalu wyborczym w dniu głosowania, mogli uczestniczyć w ustalaniu wyników oraz wnosić uwagi do protokołów głosowań ${ }^{6}$.

Celem niniejszej pracy jest scharakteryzowanie kandydatów wystawionych w okręgu toruńskim przez Komitet Obywatelski „Solidarność” oraz stronę rządową, przybliżenie ich programu wyborczego oraz wskazanie tych elementów kampanii wyborczej, które mogły mieć wpływ na wynik głosowania w czerwcu 1989 r. Bazę źródłową niniejszej pracy stanowią zbiory Pracowni Życia Społecznego Biblioteki Głównej UMK. Artykuł stanowi tylko przyczynek do szerszego opracowania zagadnienia wyborów kontraktowych w okręgu toruńskim. Aby w pełni nakreślić to zagadnienie należałoby dokonać kwerendy w Instytucie Pamięci Narodowej, przeprowadzić wywiady z kandydatami na posłów i senatorów oraz przeanalizować archiwalne filmy i audycje radiowe nadawane przez stronę rządową i solidarnościową.

\section{Kandydaci Komitetu Obywatelskiego "Solidarność"}

8 kwietnia 1989 roku powołano w Warszawie Komitet Obywatelski „Solidarność", którego celem było „zorganizowanie i przeprowadzenie kampanii wyborczej dla kandydatów opozycyjno-solidarnościowych wymienio-

Zob. DŻS, sygn. XXI - 3, Teczka: Archiwum propagandy wyborczej 1989. Koalicja, Komitet Obywatelski „Solidarności” (ulotki, afisze itp.), Informacja jak głosować wydana przez KO „Solidarność.

4 Zob. DŻS, sygn. XXI - 3, tamże, Pismo do członków Komisji Obwodowych i mężów zaufania.

$5 \quad$ Tj. Marian Kallas, Tadeusz Grudziński, Roman Backer, Michał Grabianka, Ryszard Konikiewicz, DŻS, Teczka: Wybory do Sejmu i Senatu, VI 1989 r., „Solidarność”, sygn. I -1.3.a., „Przegląd Pomorski” 1989, nr 13.

6 Zob. DŻS, sygn. XXI - 3, Teczka: Komitet Obywatelski w Toruniu, regionalna prasa oficjalna z okresu wyborów 1989 r., „Gazeta Toruńska”, 18 maja 1989 r. 
nych na jednej wspólnej liście"7. Biuro wyborcze KO poleciło regionalnym strukturom utworzenie sieci komitetów w okręgach wyborczych ${ }^{8}$. Powyższe działania umożliwiły działaczom opozycyjnym start w wyborach do sejmu i senatu pod jednym szyldem - NSZZ „Solidarność”. Finansowanie kampanii strony solidarnościowej opierało się $\mathrm{w}$ dużej mierze na wpłatach pieniężnych od obywateli. KO drukował specjalne cegiełki wyborcze, za pomocą których wyborcy mogli wesprzeć swoich kandydatów9.

Toruński Komitet Obywatelski powstał 18 kwietnia 1989 roku. Na jego czele stanął Antoni Stawikowski. Zgromadził on wokół siebie osoby cieszące się dużym autorytetem społecznym, tj.: Stanisława Śmigla - przewodniczącego Komisji ds. Propagandy, Kazimierza Kozłowskiego - przewodniczącego Komisji ds. Wyborów, i Mariana Kallasa - przewodniczącego Komisji Programowej ${ }^{10}$. Na posiedzeniu 21 kwietnia 1989 r. Komitet Obywatelski ustalił listę kandydatów startujących w wyborach $\mathrm{z}$ województwa toruńskiego ${ }^{11}$. Do obsadzenia, jak wcześniej zostało wspomniane, były dwa mandaty senatorskie oraz dwa mandaty poselskie

KO „Solidarność” w Toruniu w wyborach do senatu wystawił dwóch kandydatów. Pierwszy z nich - Stanisław Dembiński, 56-letni profesor fizyki, był dobrze znany w toruńskim środowisku naukowym. W $1981 \mathrm{r}$. w demokratycznym głosowaniu został wybrany rektorem Uniwersytetu Mikołaja Kopernika. W okresie stanu wojennego został odwołany ze względów politycznych (był członkiem NSZZ „Solidarność”). Uznanie w środowisku naukowym przełożyło się na piastowane przez niego stanowiska, m.in. kierownika Instytutu Fizyki UMK, wiceprzewodniczącego Towarzystwa Naukowego w Toruniu i prezesa Toruńskiego Oddziału Polskiego Towarzystwa Fizyczne$\mathrm{go}^{12}$. Jego wykształcenie predestynowało go do zabierania głosu w sprawach edukacji, nauki, postępu technicznego i ekologii.

Dembiński w swoim programie dużą wagę przywiązywał do problemów szkolnictwa wyższego i nauki. $\mathrm{W}$ tej materii postulował wprowadzenie

7 DŻS, sygn. XXI - 3, Teczka: Archiwum propagandy wyborczej 1989, koalicja, Komitet Obywatelski „Solidarność” , Informacja o powołaniu KO „Solidarność” Okręgu Toruńskiego.

8 Zob. tamże.

9 Zob. DŻS, sygn. I - 1. 3. a, Teczka: Wybory do Sejmu i Senatu, VI 1989 r., „Solidarność”, Apel Komitetu Obywatelskiego „Solidarność”.

10 Zob. DŻS, sygn. XXI - 3, Teczka: Archiwum propagandy wyborczej 1989, koalicja, Komitet Obywatelski „Solidarność”, Informacja o powołaniu KO „Solidarność” Okręgu Toruńskiego.

11 Zob. DŻS, sygn. I - 1. 3. a, Teczka: Wybory do Sejmu i Senatu, VI 1989 r., „,Solidarność”, Komunikat, b.d., b.m.w.

12 Zob. DŻS, sygn. XXI - 3, Teczka: Archiwum propagandy wyborczej 1989, koalicja, Komitet Obywatelski „Solidarność”, Ulotka charakteryzująca kandydatów wystawionych w wyborach przez Komitet Obywatelski „Solidarność” 
ustawy o stopniach i tytułach naukowych, która umożliwiłaby szybsze awanse pracowników uniwersyteckich ${ }^{13}$. W zakresie kształtu ustrojowego państwa, zdaniem kandydata na senatora, w polskich warunkach najwłaściwszym rozwiązaniem był system wielopartyjny i gospodarka rynkowa oparta na różnych formach własności ${ }^{14}$. W programie Dembińskiego czytamy: „Uważam, że obrady Okrągłego Stołu otworzyły Polsce szansę zrealizowania ustroju demokracji parlamentarnej [...] Należałoby zadbać o to, by okres przejściowy trwał nie dłużej niż 4 lata"15.

$\mathrm{Z}$ podobnymi nadziejami startowała $\mathrm{w}$ wyborach do senatu Alicja Grześkowiak - dr hab. w zakresie prawa karnego. Kandydatka ta była członkiem Społecznej Komisji Praworządności przy Prymasie Polski, doradcą strony „solidarnościowej” podczas obrad Okrągłego Stołu, członkiem Centrum Inicjatyw Obywatelskich do spraw reformy prawa karnego oraz współpracownikiem Komitetu Helsińskiego ${ }^{16}$. Wolne wybory do senatu otworzyły jej drogę do ubiegania się o mandat umożliwiający jej zmianę polskiego prawa.

Najistotniejszą część programu Alicji Grześkowiak stanowiły zagadnienia legislacyjne. Kandydatka postulowała m.in.: oczyszczenie kodeksu karnego ze „stalinowskich naleciałości”, zniesienie kolegium do spraw wykroczeń, uchwalenie „porządnej” ustawy o samorządzie terytorialnym, likwidację ingerencji policji w swobody obywatelskie oraz ustawowe zagwarantowanie niezależności sądów. To wszystko miało być pierwszym krokiem do przekształcenia Polski w demokratyczne państwo prawa. Zdaniem Grześkowiak „prawo powinno przestać funkcjonować wyłącznie w interesie władzy, a zacząć chronić człowieka i dbać o właściwe relacje między obywatelami i władzą"17.

Wybory do sejmu, podobnie jak do senatu, dawały szansę na zdobycie dwóch miejsc w parlamencie. Kandydatem KO „Solidarność” do mandatu poselskiego nr 383 był inżynier elektryk Jan Wyrowiński. Jako wiceprezes Zrzeszenia Kaszubsko-Pomorskiego, Klubu Inteligencji Katolickiej, współzałożyciel Klubów Rzeczpospolitej Samorządnej „Wolność - Równość -

13 Zob. DŻS, sygn. I - 1. 3. a, Teczka: Wybory do Sejmu i Senatu, VI 1989 r., „Przegląd Pomorski" 1989 , nr 9, s. 5.

14 Zob. DŻS, sygn. I - 1. 3. a, Teczka: Wybory do Sejmu i Senatu, VI 1989 r., „Przegląd Pomorski" 1989 , nr 5, s. 3.

15 DŻS, sygn. XXI - 3, Teczka: Archiwum propagandy wyborczej 1989, koalicja, Komitet Obywatelski „Solidarność”, Kandydaci - życiorys i program wyborczy: Stanisław Dembiński.

16 Zob. DŻs, sygn. I - 1. 3. a, Teczka: Wybory do Sejmu i Senatu, VI 1989 r., „Przegląd Pomorski” 1989 , nr 5, s. 5.

17 DŻS, sygn. XXI - 3, Teczka: Archiwum propagandy wyborczej 1989, koalicja, Komitet Obywatelski „Solidarność” , Kandydaci - życiorys i program wyborczy: Alicja Grześkowiak. 
Sprawiedliwość" oraz działacz opozycyjny w okresie stanu wojennego dał się on poznać jako osoba kompetentna, mająca duży posłuch w środowisku robotniczym ${ }^{18}$.

W działalności poselskiej Wyrowiński chciał położyć nacisk na odbudowę samorządności lokalnej i problematykę ekologiczną. Kandydat odrzucał centralizm demokratyczny przejawiający się w jednolitej władzy państwowej i postulował tworzenie systemu oddolnych inicjatyw społecznych. Krokiem do samorządnej Rzeczypospolitej miała być demokratyczna ordynacja do rad narodowych stojących na czele administracji lokalnej ${ }^{19}$. „Kluczem do rozwiązania problemów Polski i jej obywateli [...] jest tworzenie podstaw demokracji - $\mathrm{w}$ takim samym stopniu $\mathrm{w}$ sejmie, jak i na poziomie społeczności lokalnych. To jest teraz najważniejsze" ${ }^{20}$. Aby zrealizować te cele, Wyrowiński zdecydował się kandydować do sejmu.

Swoje miejsce w izbie niższej parlamentu widział także Krzysztof Żabiński - reprezentant Regionu Toruńskiego we władzach NSZZ „Solidarność” i przewodniczący rady pracowniczej „Merinotexu”. W działalności poselskiej Żabiński największy nacisk chciał położyć na: „rozszerzanie praw pracowniczych, problematykę związaną z warunkami pracy i płacami, naprawę struktury finansowania oświaty, nauki, kultury i służby zdrowia"21. Głównym źródłem inspiracji programowej była dla kandydata społeczna nauka Kościoła. Żabiński uważał, że przyszłość Polski należy do chadecji. Zadanie opozycji w sejmie kontraktowym miało według niego polegać na rozliczaniu władzy z prowadzonej przez nią polityki oraz dążeniu do demokratyzacji państwa polskiego ${ }^{22}$.

Wspólnym punktem programowym kandydatów „Solidarności” w okręgu toruńskim było odwołanie się do autorytetu Kościoła katolickiego. Inspiracja do działań podparta autorytetem Kościoła i opozycyjny rodowód odróżniały kandydatów „swoich” od „obcych”. Poglądy polityczne poszczególnych osób i ich programy wyborcze schodziły na dalszy plan. Zjednoczeni pod sztandarami „Solidarności” za podstawowy cel uznali zdobycie takiej liczby mandatów, która umożliwiałyby opozycji blokowanie postanowień

18 Zob. tamże.

19 Zob. DŻS, sygn. I - 1. 3. a., Teczka: Wybory do Sejmu i Senatu VI 1989 r., „Przegląd Pomorski" 1989, nr 9, s. 7.

20 DŻS, sygn. XXI - 3, Teczka: Archiwum propagandy wyborczej 1989, koalicja, Komitet Obywatelski „Solidarność” , Kandydaci - życiorys i program wyborczy : Jan Wyrowiński.

21 Tamże, Kandydaci - życiorys i program wyborczy: Krzysztof Żabiński.

22 Zob. DŻS, sygn. I - 1. 3. a., Teczka: Wybory do Sejmu i Senatu VI 1989 r. , „Przegląd Pomorski" 1989, nr 9, s. 13. 
władzy w sejmie oraz doprowadzenie, w możliwie najkrótszym czasie, do demokratycznych wyborów.

\section{Kampania wyborcza kandydatów KO}

W kampanii wyborczej prowadzonej przez kandydatów strony solidarnościowej dużą rolę odgrywała postać Lecha Wałęsy, jako gwarant jedności Związku. W celu identyfikacji „swoich” kandydatów, fotografowano ich z liderem „Solidarności” i umieszczano na plakatach wyborczych. U dołu takiego zdjęcia widniał podpis Wałęsy wraz z prośbą o oddanie głosu na danego kandydata ${ }^{23}$.

W okręgu toruńskim, zarówno kandydaci Komitetu Obywatelskiego do sejmu, jak i do senatu prowadzili wspólną kampanię wyborczą. Z wyjątkiem plakatów z liderem „Solidarności”, Dembiński, Grześkowiak, Wyrowiński i Żabiński na materiałach reklamowych występowali razem. Strategia wyborcza toruńskich kandydatów obejmowała działania w trzech kierunkach. Pierwszym była próba zachęcenia do wzięcia udziału w wyborach parlamentarnych. Przejawiało się to m.in. w sloganach wyborczych, np. „Nie śpij, bo cię przegłosują”, „Pierwszy raz możesz wybierać, Wybieraj!”. Drugim - podjęcie starań, aby głos oddany na kandydata „Solidarności” był ważny. W tym celu na plakatach umieszczano instrukcję, w jaki sposób należy prawidłowo oddawać głosy na KO. Trzecim - podkreślenie solidarnościowego rodowodu kandydatów. W materiałach prezentowali się oni razem pod charakterystycznym logiem Związku. Ponadto, ulotki urozmaicone zostały sloganami wyborczymi, takimi jak: „Twój wybór, to głos na kandydatów «Solidarności»”, „Głosuj na «Solidarność»”, etc. ${ }^{24}$ Swoją kampanię wyborczą prowadzili w opozycji do przedstawicieli partii rządzącej.

Biało-czerwone barwy, ,solidarnościowa” symbolika i patriotyczna retoryka miały zachęcać do oddawania głosów na kandydatów KO. Nie akcentowano różnic między nimi. Działania promocyjne ukierunkowane zostały na ukazanie jedności obozu solidarnościowego. Wyborca musiał być przekonany, że wybiera kandydata, który zadba o dobro Polski. Niezadowolenie z rządów PZPR-u miało się przełożyć na poparcie dla prawych ludzi o dobrych intencjach, których wcześniej nie dopuszczono do władzy.

23 Plakaty członków KO podlegały cenzurze. W prawym dolnym rogu widnieje bowiem numer cenzora, który dopuszczał je do druku, DŻS, sygn. XXI - 3, Teczka: Archiwum propagandy wyborczej Komitetu Obywatelskiego „Solidarności” 1989, Plakaty wyborcze wydane przez KO „Solidarność” przedstawiające Lecha Wałęsę sportretowanego razem z Janem Wyrowińskim, Krzysztofem Żabińskim, Alicją Grześkowiak, Stanisławem Dembińskim.

24 Zob. tamże. 
Obok plakatów wyborczych dużą rolę odgrywały spotkania z wyborcami. Bezpośrednia kampania wyborcza Stanisława Dembińskiego była prowadzona w dniach 5 maja-2 czerwca. Kandydat położył duży nacisk na agitację w małych miastach. Jego target wyborczy stanowili głównie robotnicy i rolnicy. Swój apel w ograniczonym stopniu kierował do inteligencji uniwersyteckiej i przedstawicieli kultury miasta Torunia ${ }^{25}$. Zaniedbanie tej części elektoratu mogło mieć wpływ na utracenie części głosów na rzecz Jana Kopcewicza - byłego rektora UMK.

Alicja Grześkowiak większy nacisk niż Dembiński położyła na pozyskanie głosów przedstawicieli kultury i nauki. Kandydatka rozpoczęła swoją kampanię wyborczą dopiero 14 maja. Spotkania w domach kultury, amfiteatrze, domu katechetycznym oraz auli UMK mogły mieć wpływ na poparcie uzyskane przez Grześkowiak ze strony przedstawicieli inteligencji ${ }^{26}$. Odmienną strategię przyjęli: Jan Wyrowiński i Krzysztof Żabiński. Kandydaci ci skupili się na spotkaniach z robotnikami, m.in. w kościołach, co miało podkreślić ich przywiązanie do tradycji. Wraz z kandydatami KO do senatu wzięli oni udział w wiecach wyborczych odbywających się na placach przed kościołami na Rubinkowie, w auli UMK i amfiteatrze ${ }^{27}$.

Wobec braku szerszej dostępności do środków masowego przekazu, bezpośrednie spotkania były podstawowym sposobem na dotarcie do wyborców. Przedstawiciele „Solidarności” mieli co prawda możliwość zaprezentowania się w publicznym radiu i telewizji (stanowiło to przedmiot negocjacji przy Okrągłym Stole), ale czas ten był ograniczony do minimum ${ }^{28}$.

Komitet Obywatelski w trakcie kampanii wyborczej musiał zmagać się $\mathrm{z}$ „nieprzychylną" polityką władz. Przykładem może być protest Marioli Wegner w sprawie uniemożliwienia jej przez MO zebrania podpisów mieszkańców Torunia ${ }^{29}$. Ograniczony dostęp do profesjonalnej poligrafii miał z kolei wpływ na to, że wydrukowane na powielaczu ulotki i gazetki wyborcze były mało czytelne. Mimo tych niedogodności, ogromny entuzjazm, jaki kierował działaczami „Solidarności”, przełożył się na energiczność kampanii wyborczej i umożliwił błyskawiczną reakcję wobec wszelkich nieprawidłowości, jakich dopuszczała się strona rządowa.

25 Zob. DŻS, sygn. XXI - 3, Teczka: Wybory do Sejmu i Senatu VI 1989 r. Plany spotkań posłów i senatorów - Stanisław Dembiński.

26 Zob. tamże, Plany spotkań posłów i senatorów - Alicja Grześkowiak

27 Zob. tamże, Plany spotkań posłów i senatorów - Jan Wyrowiński, Krzysztof Żabiński.

28 Zob. DŻS, sygn. XXI - 3, Teczka: Archiwum propagandy wyborczej Komitetu Obywatelskiego „Solidarności” 1989, Program Radia „Solidarność, Program Telewizji Polskiej pod redakcją KO.

29 Zob. DŻS, sygn. XXI - 3, Teczka: Archiwum propagandy wyborczej 1989, koalicja, Komitet Obywatelski „Solidarności”, „Przegląd Pomorski” 1989, nr 8, s. 2. 


\section{Kandydaci strony rządowej}

W okręgu toruńskim przedstawiciele partii rządzącej mieli zagwarantowany mandat $\mathrm{nr} 381 . \mathrm{Z}$ ramienia PZPR-u o ten mandat ubiegali się: Marian Żenkiewicz - inżynier elektryk, Marian Lipiński - technik energetyk, Lech Jagodziński - mechanik samochodowy, Maria Brzoskiewicz - inżynier rolnik. Mandat nr 382 był natomiast przeznaczony dla członka organizacji katolickich działających w ramach systemu PRL-u. Władza wystawiła tu do rywalizacji: działacza PAX - Kazimierza Jaworskiego i nauczyciela akademickiego Stefana Juliusza Janusza ${ }^{30}$. Mimo że mandaty nr 383 i 384 przeznaczono dla kandydatów niezależnych ${ }^{31}$, przedstawiciele partii ówcześnie rządzącej za „swoich" uznali: Norberta Rudnickiego i Marię Tyczyńską ${ }^{32}$. Wybory do senatu były w pełni wolne, toteż szansę w starciu z kandydatami „Solidarności” miał tylko: Henryk Wojtalewicz - prawnik i Jan Kopcewicz - były rektor $\mathrm{UMK}^{33}$.

W przeciwieństwie do członków „Solidarności” przedstawiciele strony rządowej nie afiszowali się z przynależnością partyjną. „Opowiadaj się za osobami - a nie symbolami”"34 - głosił jeden ze sloganów wyborczych PZPR-u. Wszyscy kandydaci partii rządzącej mieli podobne ulotki utrzymane w brązowej tonacji. Były one wykonane na dobrej jakości papierze, zawierały zdjęcie kandydata, jego życiorys oraz credo wyborcze. Na ulotce Mariana Lipińskiego czytamy: „Nie możemy licytować się w odwetach i żądaniach. Najważniejsze jest, aby z różnic w poglądach związkowców wynikało coś lepszego, konkretnego, coś dla zwykłego człowieka"35. Kandydaci PZPR-u starali się prezentować jako doświadczeni fachowcy, którzy pracują na rzecz prostych obywateli. Odrzucenie retoryki walki i brak negatywnego odniesienia do kandydatów opozycji miało uzmysłowić wyborcom, że strona rządowa jest zwolennikiem dialogu.

30 Zob. DŻS, sygn. XXI - 3, Teczka: Komitet Obywatelski „Solidarności”, wybory 1989, obwodowe komisje wyborcze, mężowie zaufania, Obwieszczenie Okręgowej Komisji Wyborczej w Toruniu z dnia 15 maja 1989 r.

31 Z ramienia KO „Solidarność” o te mandaty ubiegał się Jan Wyrowiński i Krzysztof Żabiński.

32 Zob. DŻS, sygn. I - 1.3.a., Teczka: Wybory do Sejmu i Senatu 4 VI 1989 r., Koalicja i inne, Region Toruń, Instrukcje wyborcze wydane przez PZPR.

33 Zob. DŻS, sygn. XXI - 3, Teczka: Komitet Obywatelski „Solidarności”, wybory 1989, obwodowe komisje wyborcze, mężowie zaufania, Obwieszczenie Okręgowej Komisji Wyborczej w Toruniu z dnia 12 maja $1989 \mathrm{r}$.

34 DŻS, sygn. I - 1.3.a., Teczka: Wybory do Sejmu i Senatu 4 VI 1989 r., Koalicja i inne, Region Toruń, Ulotka wydana przez PZPR.

35 Tamże. 


\section{Kampania wyborcza kandydatów strony rządowej}

Kampania członków PZPR-u miała charakter wizerunkowy. Na większości materiałów wyborczych zamieszczano zdjęcie kandydata i slogan wyborczy. Henryk Wojtalewicz chciał: „Walczyć o szacunek dla prawa i szacunek dla dziecka”, Marian Żenkiewicz natomiast - „Stworzyć każdemu człowiekowi perspektywy celów i szans na wyrwanie z obojętności i marazmu" 36 .

Przedstawiciele strony rządowej nie rywalizowali ze sobą. Ich kampania wyborcza była bardzo podobna, niezależnie od tego, czy byli członkami PZPR-u, PAX-u, czy „bezpartyjnymi”. Ulotki na żółtym tle z pytaniami: „Kto?, Gdzie?, Dlaczego? i W imię jakich racji?” odróżniały kandydatów rządowych od solidarnościowych ${ }^{37}$. Podobnie jak Komitet Obywatelski, PZPR przekazywała głosującym szczegółowe instrukcje, w jaki sposób mają oddawać głosy na „swoich” kandydatów. Namawiano wyborców do tego, żeby nie skreślali nazwisk z tzw. krajowej listy wyborczej ${ }^{38}$. Głosowanie bez skreśleń utrwaliło się głęboko w pamięci części polskich obywateli, dla których było ono wyrazem patriotyzmu.

Kampania wyborcza kandydatów starających się o mandaty zagwarantowane dla strony rządowej była dość niemrawa. Niekonkurencyjność wyborów wpływała na formę agitacji wyborczej, która miała charakter pasywny i mało energiczny. Władze liczyły, że uda się zdobyć część mandatów przeznaczonych dla kandydatów bezpartyjnych oraz wywalczyć znaczną ilość mandatów w wolnych wyborach do senatu.

Odmienny od członków PZPR-u sposób prowadzenia kampanii wyborczej prezentował Norbert Rudnicki - kandydat „bezpartyjny”, starający się o mandat nr 383. Opowiadał się on m.in. za: praworządnością, tolerancją i poszanowaniem godności ludzkiej, kulturą i oświatą dostępną dla wszystkich oraz skutecznym samorządem terytorialnym. Jego ulotki odwoływały się do emocji. Rudnicki występował przeciw „cenom z sufitu, choremu systemowi kredytowemu i podatkowemu i płacy, za którą trudno wyżyć do pierwszego"39. Kandydat wydał także własną gazetkę wyborczą, która miała mało profesjonalny charakter. Słabe wyeksponowanie haseł programowych,

36 DŻS, sygn. I - 1.3.a., Teczka: Wybory do Sejmu i Senatu 4 VI 1989 r., Koalicja i inne, Region Toruń Ulotki Żenkiewicza i Wojtalewicza wydane przez PZPR.

37 Zob. tamże, (Region Toruń, Ulotki wydane przez stronę rządową).

38 Zob. tamże, (Region Toruń. Ulotka - Jak głosować? wydana przez PZPR).

39 Tamże, Region Toruń., Plakat Norberta Rudnickiego. 
zbyt długa i mało czytelna lista postulatów oraz umykające w natłoku tekstu nazwisko kandydata były głównymi mankamentami jego broszury ${ }^{40}$.

Bardziej profesjonalny sposób agitacji wyborczej prezentował Jan Kopcewicz ${ }^{41}$ ubiegający się o mandat senatorski. Jego hasło: „Pragnę przywrócić młodym Polakom sens życia we własnym kraju” wskazywało drogę ku przyszłości. Dobrze wyeksponowane nazwisko kandydata opatrzone zdjęciem, na którym Kopcewicz odziany w garnitur prezentuje się jako osoba kompetentna i nowoczesna oraz stonowany niebieski kolor ulotek przełożyły się na atrakcyjność jego materiałów reklamowych. Były Rektor UMK wysyłał listy, w których przedstawiał swój program wyborczy. Obiecywał wyborcom, że jako senator będzie walczył o: godne warunki życia, nowoczesny system oświaty, ochronę środowiska naturalnego i wyciągnięcie Polski z kryzysu. Jego hasła programowe formułowane były w ten sposób, aby pierwsze litery każdego z nich tworzyły wyraz „KOMPETENCJA”42.

Reasumując, kampania wyborcza kandydatów wystawionych przez stronę „rządową" różniła się od tej prowadzonej przez Komitet Obywatelski „Solidarność". Większe możliwości finansowe władz miały wpływ na to, że ich materiały reklamowe były bardziej profesjonalne. Kandydaci prezentowali hasła programowe wskazujące na ich kompetencje, koncyliacyjność i troskę o zwykłego obywatela. Kampania strony „rządowej” polegała na wyeksponowaniu nazwisk kandydatów w nadziei na to, że wyborcy uczestniczący w głosowaniu bezwiednie powierzą im mandat wyborczy.

Strona solidarnościowa z kolei nie mogła sobie pozwolić na ryzyko utraty mandatów wynegocjowanych przy Okrągłym Stole. Postawiła więc na zjednoczenie wszystkich kandydatów pod szyldem Związku. Opozycjonistów uwiarygodniał Lech Wałęsa, który występował razem z nimi na plakatach wyborczych. Biało-czerwone barwy, dobrze znane Polakom logo „Solidarności” ${ }^{43}$ i retoryka patriotyczna miały upewnić głosujących co do wyboru „swoich" kandydatów.

40 Zob. DŻS, sygn. XXI - 3, Teczka: Archiwum propagandy wyborczej 1989, koalicja, Komitet Obywatelski „Solidarność”, Materiały reklamowe Norberta Rudnickiego.

${ }^{41}$ Prof. dr hab. z zakresu nauk biologicznych, były rektor i prorektor UMK, DŻS, sygn. XXI 3, Teczka: Komitet Obywatelski w Toruniu. Regionalna prasa oficjalna z okresu wyborów 1989, „Gazeta Toruńska” 1989.

42 DŻS, sygn. I - 1.3.a., Teczka: Wybory do Sejmu i Senatu 4 VI 1989 r., Koalicja i inne, Region Toruń, Materiały wyborcze Jana Kopcewicza.

43 Przedstawiciele Związku walczyli o umieszczenie charakterystycznego logo na obwieszczeniach wyborczych. Zamiast biało - czerwonego symbolu „Solidarności” napisanego charakterystyczną czcionką znalazła się na niej informacja o przynależności do związku napisana zwykłymi literami. Henryk Ożóg - kierownik Wojewódzkiego Biura Wyborczego stwierdził, że nie ma technicznych możliwości aby umieścić logo NSZZ. Ostatecznie na obwieszczeniu znalazł się napis „Solidarność” pisany tykwą toruńską. Dżs, sygn. I - 1.3.a., 


\section{Wyniki wyborów}

Z sondażu przeprowadzonego w maju 1989 r. wynikało, że w wyborach do Sejmu i Senatu weźmie udział $50 \%$ badanych. Tylko $31 \%$ z nich zadeklarowało, że odda głos na kandydatów „Solidarności” ${ }^{4}$. Wyniki ankiety dalece odbiegały od oczekiwań Komitetu Obywatelskiego. Jak jednak pokazały ostateczne rezultaty, ankietowani prawdopodobnie obawiali się przyznania do tego, że zagłosują na kandydatów solidarnościowych.

Oficjalne wyniki wyborów okazały się bowiem wielkim sukcesem kandydatów NSZZ. W skali kraju w wyborach do Senatu kandydatom strony „rządowej” udało się zdobyć tylko 1 mandat senatorski. Wybory do Sejmu zakończyły się absolutnym zwycięstwem strony solidarnościowej, która zdobyła wszystkie wynegocjowane przy Okrągłym Stole mandaty. W okręgu toruńskim frekwencja wyniosła $60 \%$. W pierwszej turze wyborów do senatu dostali się kandydaci KO: Alicja Grześkowiak - 75\% głosów i Stanisław Dembiński - 72\% głosów ${ }^{45}$, do sejmu: Krzysztof Żabiński - 77\% głosów i Jan Wyrowiński - 74\% głosów. Marian Żenkiewicz i Kazimierz Jaworski zdobyli mandaty nr 381 i $382 \mathrm{w}$ drugiej turze ${ }^{46}$.

\section{Wnioski}

O zwycięstwie Komitetu Obywatelskiego przesądziło przekonanie Polaków, że w naszym kraju niezbędne są radykalne zmiany. Gwarantem tych zmian mieli być kandydaci „Solidarności”. Prowadząc wspólną kampanię wyborczą, wydawali się tworzyć monolit. Program wyborczy i światopogląd poszczególnych osób schodził na plan dalszy. Wobec ogromnej siły i pozytywnych skojarzeń w stosunku do NSZZ, kampania strony rządowej była z góry skazana na porażkę. Po raz pierwszy musiała ona zabiegać o głosy obywateli, w imieniu których przez wiele lat sprawowała rządy. Okazało się, że środowisko robotnicze ma inne cele niż partia, która chciała je reprezentować.

Zdecydowane zwycięstwo kandydatów Komitetu Obywatelskiego wiązało się nie tylko z możliwością blokowania poczynań władz, ale także stwa-

Teczka: Wybory do Sejmu i Senatu VI 1989 r., „Solidarność”, „Przegląd Pomorski” 1989, nr 9.

44 Zob. DŻS, sygn. I - 1.3.a., Teczka: Wybory do Sejmu i Senatu VI 1989 r., „Solidarność”, „Przegląd Pomorski” 1989, nr 13.

45 Zob. DŻS, sygn. XXI - 3, Teczka: Protokoły głosowania w obwodach, oficjalne wyniki głosowania, meldunki mężów zaufania, informacje państwowej komisji wyborczej 1989, Oficjalne wyniki głosowania wydane przez Okręgową Komisję Wyborczą.

${ }^{46}$ Zob. DŻS, sygn. XXI - 3, Teczka: Komitet Obywatelski „Solidarności” w Toruniu. Pisma wysłane dotyczące wyborów w 1989 r., Informacja Okręgowej Komisji Wyborczej. 
rzało szansę na współdecydowanie o losach Polski. Tworząc pierwszy niekomunistyczny rząd, Polacy mieli świadomość, że dokonuje się epokowa zmiana. Mogła ona zaistnieć tylko dzięki sukcesowi, jaki odniósł Komitet Obywatelski w czerwcu 1989 roku. 